\title{
Reinventing Urban Identities in Kazan
}

\section{Abstract}

The paper aims to consider how, since the early 1990s, the city space of Kazan is shaped by different social actors. This paper assumes that a key influence on the process of social production of space in Kazan was the procedure of gaining autonomy after the collapse of the Soviet Union and the local variant of economic transformation into the global market system. From the beginning of the post-socialist transition, elites' strategies were related to the politics of memory and the ideas of multiculturalism and federalism. Consequently, Kazan underwent the process of reinventing of urban identity, and indigenization (by Hughes [2007] it was called Tatarazing) of city space. In the capital of Tatarstan the financialization of city space, accumulation through expropriation, and development by megaevents can be observed. Strategies of development enforced by elites are contested by city inhabitants and grassroots initiatives concentrated around the protection of architectural heritage. Centralized and hierarchical power in Tatarstan makes the grassroots initiatives' demands possible by a collaboration with local elites.

Keywords: post-soviet transition, urban development, political culture, elites, heritage, Kazan, Tatarstan, Russia

Kazan is one of Russia's "million-cities" and the capital of the Republic of Tatarstan. The following paper attempts to analyse and interpret the processes of urban space production within Kazan against the wider sociocultural context. Social production of space (cf. Jałowiecki 1988) is a process marked by relations of authorities, within which subjects develop specific urban strategies and onto which autonomous practices of appropriation have constant influence (Streule 2018). It is not an abstract process. Social relations, history, ideologies and authorities' constellations materialise in a physical (material) plane of urbanity; in architecture and infrastructure (Huffschmid, Wildner 2009).

The paper aims to present the process of symbolic reinventing of city space and urban identity closely related to the political and economic (systemic) transi- 
tion. Therefore, the timeframe is determined by the beginning of the $1990 \mathrm{~s}^{1}{ }^{1}$ The aim of paper is to show the role of the specific political leadership model that was formed in Tatarstan after the Soviet Union Collapse in the processes. The leadership's important feature is clannism understood there as type of political behavior when politics are organized by and around informal networks (Collins 2006: I). It is worth mentioning that the term "clan" should not be treated as a synonym of "clientelism". The objective of the paper is to avoid the reductive, orientalised discourse of regionalism and nepotism, and explore the agential character of informal networks (see: Gullette 2010; Torobekova 2013).

The article evokes the most important events in terms of theoretical assumptions. It was the establishment of the Tatarstan's autonomy within Russian Federation, related to the strengthened position of local elites. It materialised itself in urban space as part of Kazan's Millennium celebrations. Subsequently, the article discusses global trends in urban development, such as cultural promotion by the UNESCO Institution and development by the hosting of sports mega-events in Kazan. Afterwards the peculiar turning point in urban policy, ensuant from local activists' inclusion and incorporation of theirs demands into official discourse, is also characterised.

This article uses literature sources from the fields of urban policy and political culture in Tatarstan and Russia as well as the results of the author's own research on social production of space, conducted in Kazan over the period from 2018 to 2020. This study included various types of secondary sources, such as source literature, legislative acts, media and social media content analyses, as well as primary sources obtained through field research, such as interviews, participatory observations, and mental maps. ${ }^{2}$

The Republic of Tatarstan, a historical heir of Volga Bulgaria (Volga-Kama Bulghar) and the Khanate of Kazan, was annexed by the Russian Empire during Ivan the Terrible's conquests. It is located in the Volga Federal District, around $800 \mathrm{~km}$ east of Moscow, between the Volga and Kama rivers, and has a population of $3,893,800$ people. The republic is the historic homeland of the Tatars, but is inhabited by 173 distinct nationalities, which makes it one of the most multinational of Russian territories. Tatarstan's largest nationalities are, in order: Tatars, Russians, Chuvashs, Udmurts, Mordvins, Maris, Ukrainians, and Bashkirs. Islam and Orthodox Christianity are the dominant religions there, with mentions of Islam appearing much earlier, probably around $9^{\text {th }}$ century. Kazan, located at the conflu-

1 Considering the scope of the article author intentionally resign from bringing up here the issue of Public Space Development Program leading since 2015 by aid of Tatarstan President, Natalia Fishman. The paper focuses mostly on the urban development strategies concentrated around architectural heritage and those by megaevents as a trigger for grassroots initiatives activities.

2 This paper was created as a result of a research project entitled "Social Construction of Space: Anthropological Study of City-Forming Practices in Kazan” numbered 2017/27/N/HS3/02046 funded by the National Science Centre in Poland. 
ence of the Volga and the Kazanka rivers, with a current population of 1,257,391 people, has been an important trade, religious, and education centre since the Middle Ages. Since the $19^{\text {th }}$ century, it has also become an important industrial centre.

\section{Tatarstan model in action: The parade of sovereignties and strengthening of clan power structures in the post-Soviet context}

Systemic transformation in Russia coincided with the crucial identity (re)construction processes of Tatarstan's population, related to their fight for absolute autonomy. Democratisation processes of the late 1980s gave Tatar nationalists an open platform for debating national identity. This only strengthened after the collapse of the USSR in 1991, with Tatarstanian independence supporters openly exploiting the ideas of national and cultural revival, as well as the concept of recovery from colonialism, and forced Russification and Christianisation, in their demands. Tatarstan, utilising Kazan as the most visible of manifestations of Tatarstan's importance (Graney 2007: 17) in their campaign that aimed to increase the republic's political status on the cusp of 1990s, was one of the leaders of ethnic separatism in Russia. Fighting for the transformation of the Russian Federation into a truly federal and multiethnic state, they proved relatively successful in aiding the formation of a semi-independent state (Bukharaev 1999). ${ }^{3}$

Mintimer Sharipovich Shaimiev, the first president of the Republic, the guarantor of the national revival, and the national leader of "sovereignisation of state nationalism" (Bodio, Zuzankiewicz 2016), nicknamed "babai" by his subordinates, was the unquestionable hero and demiurge of these events. Shaimiev

3 During the "parade of sovereignties" (a series of declarations of sovereignty of various degree by the republics - constituents of the Soviet Union between 1988-1991), on August 30 $0^{\text {th }}$, 1990, Tatarstan announced its sovereignty with the Declaration on the State Sovereignty of the Tatar Autonomous Soviet Socialist Republic. This resulted in a series of activities that constituted autonomy of the republic: changing the name to Republic of Tatarstan, writing constitution, creating the office of the President (first elections held on the same day as the presidential elections in RSFSR - June $12^{\text {th }}$, 1991) and the government. At the same time, local authorities kept striving to be the ones to regulate regional economy, reforming social and educational policies and during 1992-1993 unilaterally determining fiscal policy in relation to the federal government (Kinossian 2012: 882-883). 1994 saw the Treaty On Delimitation of Jurisdictional Subjects and Mutual Delegation of Authority between the State Bodies of the Russian Federation and the State Bodies of the Republic of Tatarstan signed.

4 The word "babai" (tat. бабай) meaning grandfather or elder in Tatar resonates with a certain emotional softness and can be understood in the Tatarian context as the head of the family or an informal leader. By calling their first leader "babai", the people underscore their understanding of power structure in terms of kinship and the personification of power as the source of its legitimacy (see: Bodio, Zuzankiewicz 2016). 
(b. 1937) ruled the republic in one way or another for 25 years, from 1985 when he was elected Tatar Autonomous Soviet Socialist Republic's prime minister until 2010, when he stepped down after his fourth term as the Republic's president in favour of his preferred successor, ${ }^{5}$ Rustam Nurgaliyevich Minnikhanov, who previously held the office of the Republic's finance minister and PM. He continues to be an active politician as the State Counsellor of the Republic of Tatarstan, an office created especially for him after Minnikhanov's takeover of the presidency. Mintimer Shaimiev has been and will continue to be the symbol of Tatarstan's sovereignty - sovereignty he fought so hard for, often exploiting nationalistic sentiments and threatening Moscow with open conflict. Shaimiev is considered to be an exceptional politician, both in the so-called "intellectual validation discourse" 6 and in public opinion. His attributed features - wisdom, foresight, cunning, and shrewdness - are part of the conceptualisation and evolved imaginations of the Tatar ethnonym. Born and raised in a village, he has climbed every rung of the party ladder, starting with the office of the first secretary of the Tatar Regional Committee of the CPSU. His rural upbringing was an important factor in the structuralisation processes of the Republic of Tatarstan's ruling class and its mentality (Belyayev 2007: 150). The future president's worldview was reinforced in a patriarchal and conservative political environment (Ovčinnikov 2017).

The autonomy gained by Tatarstan in the first half of the 1990s allowed the state to undergo the transformation from a communist to a capitalist system on their own terms. These included a "soft landing approach" (gradualism or incrementalism $)^{7}$ in opposition to the "shock therapy" popular in Russia and other countries of the Eastern Bloc. Regional elites headed by Shaimiev managed to achieve economic growth in the Republic, in part thanks to maintaining the soviet heritage of State ownership. The other side of this effective coin of systemic

5 However, Mintimer Sharipovich denies claims that he "transferred" power to Minnikhanov (see: president's biography: Cybul'skij, Šajdullina 2016).

6 Ovčinnikov appropriately notes that the 2010s saw many publications of Tatarstanian authors, such as Bukharaev and Veselova, on local history, although many of them could be viewed as "intellectual validation" (Ovčinnikov 2017: 251), meaning academic-based validation and justification of political decisions. E.g. Veselova in her analysis of the Tatarstan model uses statements such as "the wisdom and the foresight of the Republican government is evidenced by their achievement of the complex development of the Republic, strengthening and developing Soviet heritage and its potential. Save and multiply Soviet industrial potential, and soften the crisis blow" (Veselova 2015). Bukharev, attempting to prove that Tatarstan's road to federalism is equal to democracy, writes: "Excuse my feeling of pride; a feeling shared by many who look at what's happening in Kazan. A Tatar President shows that Tatarstanian efforts for democratic federalism will not be held back merely by the change of government in Moscow. He stood steadily against the pressure from Russia, protecting Tatastan's right to determine its own future, without infringing on rights of other regions and Russia itself" (Bukharaev 2007: 66).

7 The "soft landing" approach meant a slower pace of privatization, more state regulation, some retaining of price controls, and more concern for social programmes (see: McCann 2005: 19). 
transformation, based on oil reserves after all, ${ }^{8}$ is the fact that the majority of State wealth remains in the hands of the most influential elite connected to both the previous and the current president. However, the importance of the local historical context and national and regional traditions needs to be highlighted when discussing the local-based and highly politicised economic model of the systemic transformation Tatarstan underwent after the USSR collapse. In opposition to McCann's claims (see: McCann 2005), Tatarstanian capitalism does not go uninfluenced by the global market forces, even if it remains highly localised.

The political leadership model that was formed in Tatarstan after the USSR collapse includes three important components: ethnopolitics, autocracy and clannism (Bodio, Zuzankiewicz 2016). Already in the early days of the Russian systemic transformation, the system of interconnections within the Tatarstanian elite took the form of a political clan which centred around the president and his circles: his family, friends, loyalists, clients, etc. Kinship, personal and professional relationships became the key criteria by which people joined the clan, and the intra-clan relationships formed in a hierarchical and clientelist manner. One's position within the group was largely determined by the perceived loyalty and personal relationship to the president (Bodio, Zuzankiewicz 2016 ).

To better describe Tatarstan's political system, the concept of social bonds within the political culture (as introduced by Załęski 2011) as one of the options of traditional political culture will be discussed. While the concept of traditional culture is not clearly defined (even though there are no societies without traditions, see: Jasiewicz 1987), tribal bonds are merely a starting point in Załęski's definition. Social bonds (including informal bonds) are key here. Social bonds in the political culture, in contrast to patrimonialism (Weber 2002) are not solely based on national-tribal and territorial bonds, but extend to include common experiences such as education, work, social and economic activity, which are not rooted in clientelist bonds. Rural upbringing and the traditionalistic education obtained at KIAF - Kazan Institute of Agriculture and Forestry (currently Kazan State Agricultural University) were important bonding factors in the case of Tatarstan's elites. ${ }^{9}$ Preferential treatment of Kazan Institute of Agriculture alumni could be explained by the fact that the institution was the only government-loyal Tatar-language-speaking school, but in contrast to other Kazan-based schools, it had no underground nationalist movements. KIAF was not an institutionalised headquarter of ethnic mobilisation, but rather a convenient rung on the social

8 Over 6\% of Russian oil is extracted in Tatarstan, with the extraction constituting $30 \%$ of the regional budget (Veselova 2015).

9 The Kazan Institute of Agriculture and Forestry (Kazanskij institut sel'skogo hozâjstva i lesovodstva) was established on the basis of the union of the agricultural faculty of the Polytechnic Institute and the forest faculty of Kazan University. It was awarded the status of Academy in 1995, and became a University in 2006. The main building (from 1908) is located in Kazan's historical centre, on Karl Marx Street. Both presidents of Tatarstan are alumni of KIAF. 
ladder and the only Tatar-language channel of upward social mobility for the rural Tatar-speaking population aspiring to be part of scientific and technical circles. KIAF students have related (and continue to relate) to the Tatar language in an instrumental manner, because it is their mother tongue, their daily language, not a value in itself. ${ }^{10}$

The Kazan Institute of Agriculture and Forestry has become an almost unique source of the ruling elite, much more prestigious for post-nomenclature than a university (Belyayev 2006: 164-165). Belyayev traces this back in his historical analysis. During Stalinism, the best way for a kolkhoznik (kolkhoz rural worker) to climb the social ladder was to become part of the ruling structure. Those who had technical expertise and wanted sociopolitical emancipation without breaking away from their ethnic culture and language achieved this through agricultural education (which led to power). Just $13.7 \%$ of Tatarstan's ruling elite come from big cities (Farukshin 1994), and 73\% of urban administration has rural roots (Belyayev 2006: 164). President Shaimiev treated civil servants with rural backgrounds as a tool of subversion of the countryside and reinforcement of the autocratic system (Belyayev 2006: 163).

\section{A leader amongst the regions and new politics of memory in light of expropriating urban development}

With Vladimir Putin elected Russia's president, Tatarstan lost a significant part of its political and economic autonomy which ran contrary to the "centralisation and strengthening" policies of the new political direction Moscow was taking. Simultaneously with the Public Prosecutor General's fight to void parts of Tatar-

10 Russian is the instruction language at the Kazan State Agrarian University, however students communicate mainly in Tatar. The Author met one of the employees of the University in July 2019. While speaking about her students from various parts of Russia: Tatarstan, but also Udmurtia, Bashkiria and Ulyanovsk Oblast, she highlighted that "as someone who's lived my entire life in the city, I had to get used to their mentality". The Author asked what are the features of the said mentality. The response included patriarchalism ("women are far behind in this system"), expressed as part of jokes and statements, which in her view were offensive, but her students did not source them in their ill-intentions, but rather "way of thinking in which they function". Another feature she attributed to patriarchal society was the lack of critical thinking, which she found to be an obstacle while teaching philosophy. "If someone has a mentality stuck in a box and is used to doing things only when they are being told to do them" then a lecturer "needs to think of many exercises and tasks to get their brains fired up". She also reminisced about students who "find it difficult to remember the long first name, patronymic and a surname" take liberty to call her apa (Tatar for "auntie") which makes their communication more intimate. Another person the Author interviewed, a culturalist and researcher on Kazan, claims that Tatar language as it is used in Kazan nowadays came to the city with the elites of the 1990s (interview conducted July $25^{\text {th }}, 2019$ ). 
stan's constitution ${ }^{11}$ which were incompatible with federal law, Shaimiev's Republic managed to secure significant funds for local investments as part of the compromise.

Celebrations of "1000 years of Kazan" planned for 2005 were the crowning of the "era of Shaimiev" and a catalyst for federal funding. ${ }^{12}$ Tatarstan's elites prioritised the moulding of Kazan into a significant political and economic centre of Eurasia. The city, whose role is metaphorically described as the gate between East and West in the local discourse, is a clear manifestation of not only the multiethnic reality of the Russian Federation, but also the conviction that Russian state structure is historically rooted in two foundations: Slavic and Turkic (see: Bukharaev 2007). Thus, Kazan's millennium celebrations fit in with the ambitious plans of the local elites to create and propagate the image of the city as the "Muslim capital of Russia", initiated by the city's mayor, Kamil Iskhakov ${ }^{13}$ (Makarychev, Yatsyk 2015).

They were part of a wider strategy to create a new political identity of the state. Local authority figures employed several key components of this strategy, namely the discourse of ethnicity and postcolonialism, politics and the language of the media, and architecture and discourse of heritage (Kinossian 2012: 883). Kazan's urban spaces were gradually indigenised, undergoing a process of strengthening the cultural hegemony of the group viewed as indigenous through symbolic interference in the cityscape (ethnic styling) and discourse practices (Szmyt 2017). Hughes (2007) described this as Tatarizing. This resulted in the marginalisation of Russian material culture, which is underrepresented in Kazan's city space, despite the domination of the Russian language.

The increase in popularity of national heritage in Tatarstan a common vision of the relationship between the past and the future, institutionalised and standardised global discourse (see: Bloch 2016), stems from the state's cooperation with UNESCO in the late 1990s and its attempts to get Kazan's Kremlin added to the World Heritage List. ${ }^{14}$ At the time, the Kazan's Kremlin was under renovation,

11 Especially parts concerning Republic's sovereignty, Tatarstanian citizenship, and President's required bilinguality. A new deal between the Republic and the federal centre was reached in 2005, which gave Tatarstan rights to the reserves and made Tatar language one of the official languages.

12 Kazan's Millennium is an example of an invented tradition designed to strengthen national identity and legitimise the elite's right to call on cultural values. Discovery of a Czech coin from the $10^{\text {th }}$ century in Kazan's Kremlin served as an excuse to announce the anniversary. Naturally, there were historians who disproved this dating of Kazan (see: Zharzhevskiy 2019: 65). Kazan's Millennium preparations cost RUB 64.9 billion over 5 years, with RUB 19.8 billion coming from the federal budget (Veselova 2015).

13 Kamil Iskhakov was the Chairman of the Kazan City Council Executive Committee from 1989 to 1991. Between 1991 and 2005, he was Member of the Kazan City Council of People's Deputies, Chairman of the Kazan City Council of People's Deputies, and Head of the Kazan City Administration.

14 UNESCO and Icomos cooperations are good examples of Tatars' tendency to strive to lead in many areas and for rivalry with other regions of the Federation (including the famous battle with Nizhny Novgorod for the title of Russia's Third Capital, in which Kazan emerged victorious by 
and the site's main attraction - Russia's largest mosque, the new symbol of the city and the Republic, and the support for Tatars' identity across the world (see: Kinossian 2012: 884), Kul Sharif - barely had its foundations laid. ${ }^{15}$ So how did the Kazanian elites manage to get a building that was not only unfinished but also had dubious historical authenticity added to UNESCO's World Heritage List? The idea of peaceful coexistence of nations and religions was the focal point of the concept as presented to UNESCO by the Ministry of Culture.

From that moment on, to give justice to both nationalities of Tatarstan, Kazan's Kremlin housed both the Orthodox Cathedral of the Annunciation and the mosque. The then-Minister of Culture and one of the initiators of the UNESCO cooperation explained this success also by the favourable global attitudes (conflicts about religious symbols in public spaces in Western Europe and growing Islamophobia) and proudly highlighted Tatars' ingenuity in approaching the UNESCO application. ${ }^{16}$ The Kremlin transformed from a neglected headquarters of a few Ministries into a tourist attraction of the Volga Region and a source of pride for Kazanians. Undoubtedly, this process benefited the local society as Kazan's Kremlin is characterised by a higher degree of inclusivity, with the symptomatic exception being the iron-gated Presidential Palace located within its boundaries.

Preparations leading up to Kazan's Millennium celebrations brought spectacular investments in a short period of time. The banks of Kazanka river were connected by a newly built Millennium Bridge, the first line of the Kazanian metro (planned since the 1980s) was finalised, and two main representative streets of the centre (Moscow and Sverdlov) were revitalised. Sverdlov Street was also renamed Petersburg Street to mark the friendly relationship between the two cities. ${ }^{17}$

outrunning the competitor in registering the trademark in Rospatent by couple of days). Out of 29 of Russia's World Heritage List places, 3 of them are in Tatarstan (and they are the only ones in Volga Federal District): Kazan's Kremlin (listed in 2000), Bolgar Historical and Archaeological Complex (listed 2014) and the Assumption Cathedral and Monastery of the town-island of Sviyazhsk (listed 2017). Bolgar, an early settlement of the civilization of Volga-Bolgars, which existed between the $7^{\text {th }}$ and $15^{\text {th }}$ centuries $\mathrm{AD}$, was the first capital of the Golden Horde in the $13^{\text {th }}$ century. It is a symbolic reminder of the acceptance of Islam by the Volga-Bolgars in AD 922 and remains a sacred pilgrimage destination to the Tatar Muslims. Sviyazhsk is a symbol of Russian rule, as it was founded by Ivan the Terrible in 1551 and it was from this outpost that he initiated the conquest of the Kazan Khanate in the $16^{\text {th }}$ century.

15 Kul Sharif Mosque was built between 1996-2005 as a "reconstruction" of a legendary mosque of Kazan Khanate's capital dated to the $16^{\text {th }}$ century. The building is a hundred percent contemporary intervention into Kremlin's space, an example of postmodernism in architecture.

16 Speech by Rafael Valeyev, member of the International Council on Monuments and Sites, Head of UNESCO Institute at Kazan Federal University under "Citizen School", entitled World and natural heritage of the Republic of Tatarstan from June $20^{\text {th }}, 2019$.

17 St. Petersburg celebrated its $300^{\text {th }}$ Anniversary in 2003. As a gift to Kazan for their millennium celebrations, the city renamed one of the city centre's historic streets in the "second capital of Russia" to Kazan Street. 
2004 saw the founding of The Museum of the Millennium of Kazan, presenting the history of Kazan and Tatarstan since the beginning of time and highlighting the autonomy of the indigenous Tatar people. The Gently Assembly building was also renovated, housing Kazan's town hall, and exhibition and concert halls. This is also where the Commonwealth of Independent States (CIS) had its summit, with presidents of Russia and Kazachstan participating, which strengthened the status of Kazan and validated Shaimiev's influence in both Russian and international politics.

\section{The protection of architectural heritage as a fight for Kazanians' right to the city}

Kazan's millennial celebrations were a turning point for the city, especially if taking the extent of interference with urban fabric that took place under consideration. The process of liquidating housing stock and reconstruction of the districts of ramshackle quarters (vetkhoye zhil'ye) in place between 1996-2004 is another historically significant interference with Kazan's city structure. The programme inaugurated by President Shaimiev in $1995^{18}$ was one of Tatarstan models' social programmes and a response to the dire residential needs of the city. It was once again a novel approach, the first of its kind in the Russian Federation. Most slum housing in Kazan, dated usually to be between $19^{\text {th }}$ and $20^{\text {th }}$ centuries, were located in the city centre. The programme saw the construction of 1,763 residential buildings divided into 52,835 apartments with a total squareage of 2,905,900 square metres and the freeing of 1100 hectares of urban lots (Valeyev 2010). The programme paced up with the coming of the Millennium celebrations, and regeneration of the slum housing in the city was made a priority.

1996 saw over 20,000 Kazanian families living in difficult or unlivable conditions. Even though the programme of liquidating ramshackle dwellings allowed people to move from inadequate housing to newly constructed buildings, those inhabiting the historic city centre were forced to move to the bedroom suburbs, where the market value of their housing was much lower. Attractive urban lots in the centre, managed by self-interest-guided civil servants, attracted developers and businesspeople planning on constructing multi-floor hotels, shopping centres and other elitist real estates, which led to some machinations and malpractice, and sometimes abuse (Valeyev 2010). First of all, the freedom to reallocate was a freedom in theory only. Inhabitants of ramshackle dwellings were often pressured,

18 "O merah po ulučšeniû žiliŝnyh uslovij graždan, proživaûŝih v vethom žiliŝnom fonde,

i rekonstrukcii kvartalov vethogo žil'â", http://docs.cntd.ru/document/917009089 (access: 12.10.2020). 
whether administratively or directly, to move. The State Housing Fund ${ }^{19}$ and urban structures were meant to be responsible for reconstructing the districts and for maintaining their historical and architectural authenticity, and property rights to lots deserted by reallocated people were to be transferred to investors who would reconstruct the dwellings and other precious historical locations (Valeyev 2010).

The reality of this process was markedly different. $42 \%$ of 8001 locations under the programme was to be restored and renovated, and $58 \%$ to be demolished. ${ }^{20}$ Against authorities' assurances about the supposed renovations, over $80 \%$ of the locations were demolished (or burned down in unexplained circumstances). "Protection and development of Kazan's historic city centre", a federal programme started in 2001, assumed renovation of 86 buildings, with only 35 actually renovated. The funding from this programme went to other projects deemed integral to the Millennium celebrations, such as the first metro line, the Millennium Bridge, the hippodrome, or a modern Social Security Agency building in the city centre (Grafeyev, Valeyev 2015). Revitalisation of the central streets, namely Petersburg, Moscow, Tatarstan, Pushkin and others, proved controversial. Newly renovated streets lost their historic character and the newly constructed buildings, of dubious material and aesthetic worth, in stark contrast with their surrounding environment, became aesthetically outdated the moment construction ended. Many of the buildings on central streets with high tourist traffic only had their facades renovated. When looking into their courtyards, one can easily see that their complete overhaul is far from being over. ${ }^{21}$

The programme of liquidating the housing stock and reconstructing slumhousing districts, because of the huge demand for residential properties in Kazan and the level of negligence of the historic centre prior, is presented by the Republic's elites as a huge socio-political accomplishment and is interpreted generally positively by external observers (see: Bukharaev 2007; Veselova 2015; Valeyev $2010^{22}$.

19 Gosudarstvennyj vnebûdžetnoj žiliŝnoj fond Respubliki Tatarstan.

20 Resheniye KSND ot 30.10.1996 N 1-5 "O programme likvidatsii vetkhogo zhilogo fonda i rekonstruktsii kvartalov vetkhogo zhil'ya v Kazani” // Respublika Tatarstan, http://tatarstan.newscity.info/docs2/sistemaf/dok_pedhfi/index.htm (access: 13.04.2015).

${ }_{21}$ One of the respondents, a 20-year-old artist-photographer, initiated a walk around the courtyards of Kazan's main streets during our perceptual walk, to "show the author, (an anthropologist), how the city they study really looks". The walk turned into a long and critical discussion of urban politics and policy, and politics in general, and ran in stark contrast to a widely held belief about the lack of political awareness amongst the youth (interview conducted November 17th 2019 ).

22 A.R. Valeyev (2010) writes: "It needs to be noted that some politicians and researchers view the liquidation programme in Tatarstan in a one-sided perspective of it being a populist attempt of the local authorities to ease social tensions and free historic centre's lots to be developed for elites. However, the importance of this programme is far more reaching. It is directly connected to solving economic, social and moral issues. In the economic aspect, it helped save the urban industry, especially in construction, and gave work to thousands of people". He further says of the invaluable social 
The presidential programme, however, is also a part of the negatively viewed phenomenon of accumulation through expropriation (see: Harvey 2012; Sassen 2014; Juskowiak 2015). It is a process where resources are extracted from the hitherto existing social networks and transformed into property, which is then subject to capitalist accumulation (Kusiak 2019: 653). This example of the urban form of accumulation has been supported in later years by a strategy of restructuring through mega-events, which will be discussed in subsequent parts of this paper. The process of repurposing and revalorising Kazan's existing infrastructure fits in with the global trends of urbanisation as a tool of expansion and reproduction of the capitalist mode of production (Juskowiak 2015: 94). This is exemplified by the fact that in place of authentic architecture in the historically Tatar neighbourhood (Old Tatar Sloboda), new-made-to-look-old (so-called novodel) commercial buildings popped up: restaurants, hotels, galleries, and private museums. This is indicative of the commodification of urban lifestyle and aesthetics (Juskowiak 2015: 94). Their purpose is to sell a particular urban lifestyle to visiting tourists. In this case, it's the urban culture of Kazan's Tatars.

The abrupt changes to the city's fabric, especially the demolition of historic architecture, were faced with social opposition. The main stakeholders of this protest were the representatives of Kazan's cultural and scientific elites, people connected to the Tatarstan regional branch of the All-Russian Association for Protection of Historical and Cultural Monuments, ${ }^{23}$ journalists, tour guides, scientists, and students. They fought to highlight the issue of disappearing material forms of cultural heritage, and to regulate socio-legal status of architectural monuments, viewed as the basis of the city's spatial identity. It should be highlighted that preservation of heritage was not a popular topic back then in Russia, with the introduction of the law on preserving cultural heritage of nationalities of the Russian

importance: "Thanks to the programme, many young people could start a family, which is evidenced by the number of marriages officiated. By resettling the population from ramshackle into well-fitted flats, Republic's authorities demonstrated a high level of responsibility for the nation. It was incredibly important for maintaining sociopolitical and economic stability in the Republic".

${ }^{23}$ In Russian: Vserossiyskoye obshchestvo okhrany pamyatnikov istorii i kul'tury. All-Russian Association for Protection of Historical and Cultural Monuments was founded in 1966 by the government of the The Russian Soviet Federative Socialist Republic (RSFSR). With time, the Association grew to become an organised mass movement, with over 17.5 million members in early 1980s and operations across the entire RSFSR with affiliated organisations springing up in institutes, enterprises and factories. The mission of the Association is to locate, submit, study, protect, renovate and market monuments of history and culture. It was financed by membership dues. The Association was given the right to give expert opinion on the locations/buildings and was an important entity collaborating with authorities for monument protection. It also distributed renovation funds; co-financing renovation-conservation works for almost 200 buildings between 1968 and 1971. By 2000 , they funded restoration worth around RUB 10.5 billion. Russian systemic transformation had a significant impact on the organisation, with membership dues eliminated and free market dynamics suppressing the Association's financial situation: some regions of Russia even saw its divisions disappearing (Polyakova 2005: 243-246). Tatarstanian Division reactivated in 2009. 
Federation being introduced for the first time in 2002. ${ }^{24}$ The law was amended 48 times over the years, which is indicative of how controversial this topic is. There are multitudes of conflicting interests surrounding historic monuments' preservation and the revitalisation of Russian cities, which are directly related. Small-scale civic activism, such as pickets in front of buildings to be demolished, accompanied institutionalised efforts. ${ }^{25}$

Field research revealed multiple respondents reporting trauma as a result of the central districts' demolition. During fieldwork a new hitherto undiscussed theme emerged. In unofficial conversations, Kazanian stereotypes revealed the attitude that the local administrators are ruthless Tatars from the countryside (marginal status of rural upbringing in the urban culture was to be offset in Tatarstanian post-nomenclatura by unbridled ambition and hard work) who invaded Kazan. Foreign to their identity, the city could be exploited for development experiments. ${ }^{26}$ Trauma expressed by the respondents may legitimise the characterisation of the process Kazan underwent as an urbicide, understood by Berman (1996) as the destruction of physical urban environment: places, monuments, sounds, activities, and institutions; and eliminating particular forms of social life. Urbicide can occur in various dimensions and can as such be understood in various ways: from cities' physical destruction as a result of an armed conflict (Coward 2004, $2008)^{27}$ to an urban revolution, defined by Lefebvre (2003) as a process where pre-

2426 Federal'nyy zakon $\mathrm{Ob}$ ob"yektakh kul'turnogo naslediya (pamyatnikakh istorii i kul'tury) narodov Rossiyskoy Federatsii ot 25.06.2002 N 73-FZ (poslednyaya redaktsiya). Available at: http:// www.consultant.ru/document/cons_doc_LAW_37318/(access: 16.07.2020).

${ }_{25}$ Sociology students at Kazan Federal University organised pickets outside of Rector's Karl Fuchs $19^{\text {th }}$ century home which was qualified to be demolished as part of their laboratories on city activism (see: Yasaveyev 2013).

26 Belyayev goes a step further in his critique (2006) stating that ridding Kazan of its material and cultural heritage is an act of revenge on the city; aggression and cowardness resulting from elites' own low self-worth (who he calls "marginals") and a proof of their vindictiveness (Belyayev 2006: 172).

27 The need to delve into the phenomenon of city's built environment destruction came about after Mostar's architects published their “Mostar'92 - Urbicid” (Ribarević-Nikolić, Jurić 1992) who in order to highlight the dire situation of the architecture of former Yugoslavia presented Mostar's physical destruction as the main aspect of the ongoing war (Coward 2008: 35-37). Urbicide appeared as an appropriate analytical category in the post-Cold War era in the context of internal conflicts of former Yugoslavia, former USSR and in the Middle East, and in this context violence was interpreted as an attack of rural traditions' reactionary forces on the cosmopolitan urbanity of cities. This approach makes it difficult to avoid antagonising cities and countryside. Bogdan Bogdanovic described city haters and the city as the object of hate as urbicide, and Donia and Fine (1994) accuse "uneducated weaponised savages with hateful attitudes towards the city culture and city institutions" of "excess violence" during the 1992-1995 Bosnian War. Urbicide as a concept bears risk of triggering differences and stereotypes, such as traditional vs. modern and cultured vs. ignorant, which turns into valuing urban existence over one perceived as rural (Grodach 2002: 77). The aim of this article is not to deepen the city vs. countryside dichotomy. However, it needs to be noted that city's cultural elites distance themselves (through e.g. exploration of the Bulgar identity 
capitalist cities are superseded by global cities, entangled in the Eurocentric global economy; cities created as a result of neocapitalist urbanisation.

These phenomena are linked together by the alienating, inequality-conducive and homogenising force of neoliberal capitalism. Urbicide, in its intensified and systematic form of violence, becomes a core feature of global capitalist urbanisation (see: Goonewardena, Kipfer 2007). Kazan's inhabitants not only experienced the feeling of alienation from urban space, which affected them emotionally, but they also felt significantly disrespected by the authorities who failed to inform the public about their plans. The lack of communication and cooperation with inhabitants (to be precise: the failure to ask the public for their opinion) could be taken by the public as a great problem with urban policy.

\section{The marriage of elites and activists as an effective way to reclaim the city}

Mintimer Sharipovich founded the Republican Fund of Cultural and Historical Monuments Revival ("Revival" 28 for short) by a presidential decree the day before his resignation from the office of the President. ${ }^{29}$ Heading this informal institution gave Shaimiev, on the one hand, a huge source of financing, ${ }^{30}$ and on the other the opportunity to maintain the power, symbolically as well as materially. The "Revival" foundation's main goal was to renovate Bolgar's and Sviyazhsk's architectural and archaeological monuments. The construction of sacral spaces in these locations, although officially commissioned to strengthen interfaith and intercultural bonds within the Republic, was in fact a continuation of the regional policy of remembrance and creation of the "concept of the nation [of Tatarstan]" (see: Ovčinnikov 2017). The immensity of funds and effort employed to promote

as opposed to the Tatar) often by crediting themselves as "Kazan's intelligentsia" in opposition to political elite of rural origins and as such expose identity considerations in the Kazanian model of urbanisation, which translates into the development path the city is taking.

28 ("Respublikanskiy Fond vozrozhdeniya pamyatnikov istorii i kul'tury Respubliki Tatarstan" Fond „Vozrozhdeniye").

29 A new Act reconfiguring the way regional government is established, initiated by Vladimir Putin, was introduced in 2004. The Beslan school siege of 2004 and thus the "war on terror" were used as an excuse for the change in legislation. Candidates for heads of regions were nominated by the President of the Federation, and accepted by the legislative body of a given region (in Tatarstan that is the State Council of the Republic of Tatarstan (rus. Gosudarstvennyj Sovet Respubliki Tatarstan). When Mintimer Shaimiev decided not to run for reelection, the President of Russia, Dmitry Medvedev, recommended Rustam Minnikhanov, the then-Prime Minister of the Republic, whose nomination was unanimously accepted by the State Council.

30 President Shaimiev called on his citizens to donate to the Fund. Financing came from state organisations, municipal and private enterprises, and was taken from workers' salaries, often against their wishes (see: Ovčinnikov 2017). 
Bolgar and Sviyazhsk, which soon became the most important centres of tourism and pilgrimage in the region after Kazan, is directly proportional to the level of degradation that the material heritage of the capital and other cities of the Republic suffered.

Shaimiev's successor, Rustam Minnikhanov, continued with ethnocratic policies, although federalist and sovereignty attitudes were somewhat overshadowed by strategies attracting investment. Moreover, maintaining a strongly politicised local economy, based on connections and elite networks, and being a regional leader was viewed as a guarantee for a good relationship with Moscow. ${ }^{31}$ Minnikhanov's circle saw Asian authoritarian modernisation as an inspiration. The Agency for Investment Development even invited Mahathir Bin Mohamad, the father of the "Malaysian economic miracle" to visit Kazan in 2010. Rustam Nurgaliyevich is even said to have stated during one of the meetings on new technologies that "you need to be a Deng Xiaoping or a Lee Kuan Yew, not a Kim Jong-Il". ${ }^{2}$

The "Minnikhanov' era" would be remembered as an era of urban development defined by the mega-events. Kazan had campaigned to organise the 2013 Summer Universiade since the early 2000s, in line with Shaimiev's vision of the city being Russia's sporting capital. The exploitation of mega-events as a way for quick development and obtaining federal funding exists elsewhere in the Russian Federation (Trubina 2015: 9), however Kazan's sport infrastructure will not be deserted the way Sochi's was after the Winter Olympics. ${ }^{33}$ In the case of Universiade infrastructure, they were transferred under the federal budget (Veselova 2015: 19)

31 The region, even though it demonstrates political loyalty to the federal centre, is the only one in Russia that managed to retain the title of the President for its top executive. Tatarstan's elites prove that the Republic is a place of innovation. It is a home for the Russia's first technopoly (IT-city of Innopolis which gained city rights in 2015 and was founded in proximity to Kazan in 2012) with its own university, special economic zone, and social infrastructure for new technology workers. While still the finance minister and Prime Minister, Minnikhanov, while promoting the Alabuga Special Economic Zone in the north-eastern part of the Republic, is said to have stated that "who stands against the Zone, stands against me" (see: Veselova 2015) which proves the strength of the personification aspect of processes legitimising power. There is no division between political and economic elites in Tatarstan: the Ministry of Land and Property relations of the Republic of Tatarstan is a sole shareholder of the Alabuga; Minnikhanov was the chair of Board of Directors of the Tatarstanian Tafneft - one of Russia’s biggest oil companies (for more details, see: McCann 2005: 49-50).

32 From: “«On znaet žizn”»: 17 mgnovenij vesny Rustama Minnihanova”, https://www.businessgazeta.ru/article/338446 (access: 10.10.2020).

33 Universiade cost RUB 230 billions (roughly EUR 5 billions at 2013 prices), with 68 bn coming from federal budget and 81 bn from Republic's budget (Veselova 2015: 19). Universiade's essential investments included the city infrastructure which was modernised. These developments included: a completed "Big Kazan Ring" with a new 23 km LRT (fast tram), light train connecting to the airport, new airport terminal and renovation of the old one, rail station renovation, $65 \mathrm{~km}$ of new roads, 63 city streets and 41 pedestrian crossings. 64 new buildings were constructed for the Universiade, including 33 sports arenas. These include the olympic village (Dierjewnia Uniwersjad), football stadium with capacity of 45,000 spectators (the Kazan Arena), "Ak Bars" palace of martial arts, volleyball academy, tennis academy, and a raceway at Kaban lake. 
and since 2013 the Republic has been organising other international sports events, such as the FIFA World Cup 2018 inclusive. Mega-events are also a good excuse to implement ethnic representation in visual branding: the brand identity of the event features a Tatar ornament, and stylised souvenirs fill the shops. An experienced city tour guide, when interviewed by the Author, stated that international and Russian tourists look for Kazan's famed uniqueness and the oriental vibe and expect the city to immerse them in the authenticity of the widely yet imprecisely defined East. ${ }^{34}$

Preparations for the Universiade and continued reinvestments in the city only exacerbated social discontent, and the protests grew in numbers and became more organised. They often took the form of pickets in front of buildings to be demolished, petitions or exhibitions. Although the pickets did not gather crowds, they were widely commented on in public. The internet became an arena for criticism of the development strategies of the country and its authorities' actions, and such critique also came to influence these processes (see: Gessen 2017). Guided tours of lost buildings, which attracted considerable attendance, were another form of Kazan citizens social protest against chaotic and lawless demolition and construction. The Association for the Protection of Monuments, with a growing number of architects, historians, and excursionists and other local members of cultural elites, supported by popular bloggers, also joined in the action. City activists working for the protection of material heritage judge the "second wave of monuments' protection" (as opposed to the first one during the millennial celebrations) as more effective. ${ }^{35}$ Acts of social discontent were not unique to Kazan; Russia saw growing protest movements across the country's cities since the mid 2000s. These also shared a common theme as they opposed lawless intervention into the city's fabric such as increased urban density, clearing of greenery, and the demolition of architectural monuments (Zhelnina, Tykanova 2019: 163). ${ }^{36}$ The optics of conflicts involving a non-governmental organisation and a nonrepresentative centre of the capital, reflecting the dire inequalities, in the face of the upcoming Universiade was bound to make the administration anxious. ${ }^{37}$ In August 2011, Olesya Baltusova, a 29-year old journalist and city travel guide, member of the Association for Protection of Monuments, published an emotional and brave letter addressed to the president of Tatarstan in which she depicted the situation of Kazan's space.

The letter was in the form of an invitation for a Baltusova-guided walking tour along "these places in this adored city which managed to hold onto their own

34 Interview conducted on July $29^{\text {th }}, 2019$.

35 Interviews conducted by the Author in December 2017, January 2018 and July 2019.

36 Similarly in Kazan: the protests against demolition of monuments as presented in this article were not the only ones. Many other activist movements were also present, amongst them ones for fair elections, against exclusion of people with disabilities, against the new general plan, or pro-greenery and pro-animal protection.

37 The interview with a city activist was conducted in December 2018. 
style", "a central tourist street, where not a single public toilet is located, so tourists are advised to nip around the corner", or "the oldest house in Kazan", which is an excuse to highlight the effects of the millennium programme, as she states [the house] "is not from the $12^{\text {th }}$ century, not even $16^{\text {th }}$, but the beginning of the $18^{\text {th }}$ century [...] which is rather odd for a millennium-old city". She goes on to note the exclusionary way urban spaces have been repurposed with privatisation and fences, when she states she "would like to take a closer look at, but the director of the 'Adonis' factory will not allow it". ${ }^{38}$ The letter eloquently highlighted the detachment of local elites from the urban space, hence the realities of the city, which they "observe only from the windows of their limousines and offices". Her letter, unexpectedly for her, was met with a response from the President's office, who requested the guided tour to be prepared. This tour, and others that followed, resulted in Baltusova being offered a position as aide to the President of the Republic of Tatarstan by Minnikhanov, which she accepted in October 2011. In interviews, she makes a point to note that she took the position as a result of the collective decision from the circles she represents. "I said yes because the AfPM is unable to influence these processes from within the administration. So, we decided I would take this office to be able to influence at least some of them" ${ }^{39}$

Her areas of work as an aide to the President include cultural heritage sites, construction on areas under historical protection within the Republic, and the promotion of tourism and museums in Tatarstan. Apart from gaining actionable influence with regard to the administrative and legislative situation of heritage protection, including several regulations and directives on monuments she created, Baltusova remained engaged in the grassroots work of protecting specific

38 The original quotes come from Baltusova's letter whose copy was given to the Author from an informant, as the original is not available online anymore. The text itself is incredibly interesting as an ethnographic source that conveys the spirit of the city at the beginning of 2010s, subtly communicating supralocal issues facing a modern megapolis, and processes that it undergoes. These processes include the aforementioned expropriating urbanisation: "These homes that still have people living in them, whether waiting for a nice offer or a renovation are particularly important. It doesn't matter why they are still there; it matters that these homes still breathe history, warmth and soul that new architecture is so lacking", or migration: "I'll walk you past the merchant streets [...] of abandoned houses, illegally squatted by Tajikistani Roma people; they remind us of the old town, when you get the water from a well and carry it home on a carrying pole", or financialisation of public space for tourism and mcdonaldization of local traditions: "I would walk you on the street once inhabited by Tatar artisans, and they did a much better job at sewing Tatar ichigo shoes or chuvyaki slippers than we can nowadays offer to to tourists". The pursuit of agency for residents to regain the right to their city, encapsulated by the protection of disappearing heritage is also part of these processes: "I want to show you the treasure room of Evgeny Kanaev, Kazanian artistphotographer. Evgeny has a treasury full of items collected around the entire Kazan". The Author also visited Evgeny Kanaev during a field research trip in December 2018. In a small room in an old house in a historic Tatar neighbourhood, Kanaev collects furniture, appliances, private memorabilia, photographs, letters and many other artefacts from the demolished buildings.

39 The interview was conducted by the Author on January $9^{\text {th }}, 2018$. 
buildings from demolition, but now exploiting her extended network and with actual authority behind her. ${ }^{40}$ The aide also curates "Tom Sawyer Fest", a grassroots initiative that renovates old houses with the help of volunteers.

Introducing a charismatic NGO worker and social activist into the administration could be viewed as an attempt to mitigate social discontent by the government, and a direct cause of the diminishing critique coming from the activist circles. ${ }^{41}$ In the Tatarstanian context however, it can also be viewed as an attempt to create space for communication between the government and society, which is severely lacking, and one of the main reasons for socio-political apathy (see: Zhelnina 2019). Baltusova herself ended up being exposed to increased criticism and blame for any cultural heritage lost during her term. Both Baltusova and other experts on cultural heritage prominent in media and culture respond to the attacks of the so-called "couch critics" with arguments that they are silently doing "real work". However, this ambience of glorifying effective actions in opposition to online criticism, accompanied by distance created by elites (this time "expert" elites) from the common man, is creating another communication barrier.

Over the last several years, due to increased public interest in city politics (and policy), evidenced by not only increased online activity ${ }^{42}$ but also organised protest, ${ }^{43}$ as well as grassroots work from heritage protection circles, official and non-governmental organisations (Baltusova's office included), Tatarstan's elites headed by Minnikhanov changed the official discourse on heritage and included sustainable development as a concept. ${ }^{44}$ January 2019 saw an interdisciplinary

40 For more on formal and informal structures see: Zhelnina, Tykanova 2019; Turowska 2019.

41 During the opening ceremony for another edition of "Tom Sawyer Fest", President Minnikhanov made this evident when he described Baltusova from the stage as a "person who criticised the authorities is now working with the same authorities to protect this heritage", https:// www.youtube.com/watch?v=D6ySBnmNW4\&list=PLmvkgdNfiTJwXm2u8feWF3FQJT8vbEJ2H\& index $=3 \& \mathrm{t}=6 \mathrm{~s}$ (access: 1.10 .2020$)$.

42 Social media features popular channels where Kazanians exchange information about the old buildings, stories about particular city spots, such as "Kazan Nostalgique" Facebook group, or "Arkhitekturasy" Telegram channel. Before-and-after or then-and-now posts comparing old and contemporary photos with user-generated personal stories are popular. People also organise in thematic chats, which helps grassroots movements grow. No demolition or lawless construction will manage to escape public's attention anymore.

43 Kazan saw organised protests by its citizens against e.g. stipulations of the new general plan for the city being drafted since 2015 and announced in 2020.

44 President Minnikhanov also admitted publicly that the development policy of the city was flawed during the meetings of Interdepartmental Commission on Construction on Historic Areas in 2018 when during discussion on the future developer projects to build a skyscraper he stated: "we made many mistakes already, this will not be correct" (September 2018, [https://www.tatre.ru/ articles_id19090]), or "every day I look out of the window and I feel remorse" (April 2018, [https:// www.youtube.com/watch? $\mathrm{v}=\mathrm{cWm} 3 \mathrm{mDjTUtM}]$ ). This resulted in an authoritarian ban on construction higher than 5 storeys in Kazan's historic centre, which is a significant and limiting simplification (interview conducted with a Kazanian architect conducted by the Author on October 15 ${ }^{\text {th }}, 2019$ ). All projects bar one were "frozen" until the sustainable development plan was to be put in place. The 
team of experts on architecture, urban studies, economics, law and social sciences brought to life, with the aim of creating a cohesive and consistent methodology for architectural design in Kazan's historic centre mindful of sustainability. The team was directed by Kazan's mayor Ilsur Metshin, President's aide Baltusova, the chair of Kazan Ispolkom, and the city architect. The "Centre of Kazan Sustainable Development" project was set up to conduct complex research on the history and architecture of the city, analyse legislative documents and economic strategies, and provide social studies. According to people involved, it is aimed at facilitating design procedures firmly in line with the local historic spirit, and at creating common "rules of the game" for the stakeholders (investors, the government, and citizens) to avoid the loss of material heritage and conflicts about the city space resulting from the lack thereof. Even though there was some form of social participation at the conceptualisation stage of the project, and it comes from the demands and needs of the people and the grassroots movements, it is still a formalised process, imposed from the top. The project's executor and an ex-activist turned expert stated in an interview: "It is a tool. And we must use the tools we have available. Otherwise, we may as well do nothing." ${ }^{45}$

\section{Conclusion}

The past thirty years saw Kazan, the capital of Tatarstan, undergo significant changes and transformation mirroring the realities of federal policy and the situation in which particular global urban development trends adapt to the specific sociocultural context. The Tatarstanian elite's efforts to regain autonomy in the early 1990s resulted in indigenisation (tatarising) of the urban space. Even though the visual overrepresentation of Tatar culture in public urban space does not reflect the ethnic demographics of the city well, it cannot be said that the conflict about cultural heritage between the government and activists and experts is based on an ethnic division between Russians and Tatars.

The be noted that different actors, through joining the informal networks, have a real financialisation of the real estate market that came alongside systemic transformation resulted in deep changes to the city's structure based on the resettlement of the city centre's residents and reinvestment in the freed city lots. This

only one to go ahead was the 2019 construction of a new building owned by Gulsina Akhatovna, Minnikhanov's wife, in place of a Zdorovie Combinat (Kombinat "Zdorov'ye"), a 1978-built sports and recreation complex with baths demolished in 2017. It is worth noting that since 2015 a massive revitalisation of public spaces project named "Parks and squares of Tatarstan" curated by another aide to the President, Natalia Fishman, is in operation. Moreover, from 2019 there is a wide-catch public programme of revitalisation of courtyards called "Nasz Dvor". Because of inherent volume limitations of this work, the Author decided not to discuss these programmes in greater detail.

45 Interviews conducted on December $15^{\text {th }}, 2019$. 
had substantial influence on Kazan's sociocultural landscape. If, in the Russian paradigm, it is the old residents of the city centre that hold social capital, and the Russian gentrification is based on the cooperation of "free" market forces and authorities [even though the latter gave away part of its monopoly to regulate the real estate market in hands of private capital, it was not the invisible hand of the free market that handed out eviction notices, it was the administration (Trubina 2011)], then one can speak of "internal colonisation", understood as a political organisation of territorial relationships. "Colonisation" is a part of the State's role in reproducing relationships of production and domination (Lefebvre 1976 in: Goonewardena, Kipfer 2007).

The centralisation of the Russian Federation in the 2010s changed Tatarstan's strategy and thus transformed Kazan from the allegory of federalism and multiculturalism into the leader of investment and the Third Capital of Russia. The official discourse of Tatarstanian elites welcomed (not without the help of grassroots movements) in recent years the inclusion of sustainable development, nowadays more intensely introduced in urban policies. The case of Kazan demonstrates how urban dynamics is shaped by politics, powerful leaders with urban planning ambitions, and different agential actors originating from environments of local experts in the field of cultural heritage and grassroots initiatives. The bureaucratic structure limits many independent activities; however, it should impact on urban development strategies.

\section{Bibliography}

Belyayev V.

2006 Osnovnye cherty klanovoy postnomenklatury v Tatarstane, "Pro nunc. Sovremennyye politicheskiye protsessy", no. 4 (7), pp. 159-179.

2007 Mirovozzreniye i sotsial'noye povedeniye pravyashchel elity Tatarstana, "Obshchestvennyye nauki i sovremennost"', no. 3, pp. 150-157.

Berman M.

1996 Falling towers: city life after urbicide in: D. Crow (ed.), Geography and Identity: Exploring and Living Geopolitics of Identity, Washington, pp. 172-192.

Bloch N.

2016 Evicting heritage: spatial cleansing and cultural legacy at the Hampi UNESCO site in India, "Critical Asian Studies", pp. 1-23.

Bodio T., Zuzankiewicz P.

2016 Przywództwo i polityka etnokratyczna w Tatarstanie. Część II: Format przywództwa i style uprawiania polityki, "Nowa Polityka Wschodnia", vol. 2 (11), pp. 79-98.

Bukharaev R.

1999 The Model of Tatarstan under President Shaimiev, New York.

2007 Tatarstan: A „Can-Do” Culture. President Mintimer Shaimiev and the Power of Common Sense, Kent. 
Collins K.

2006 Clan Politics and Regime Transition in Central Asia, Cambridge.

Coward M.

2004 Urbicide in Bosnia in: Cities, War, and Terrorism: Towards an Urban Geopolitics,

S. Graham (ed.), Malden Mass., pp. 154-171.

2008 Urbicide: The Politics of Urban Destruction, London-New York.

Cybul'skij I., Šajdullina N.

2016 Mintimer Šajmiev, Moskva.

Donia R.J., Fine J.V.A

1994 Bosnia and Hercegovina. A Tradition Betrayed, London.

Farukshin M.

1994 Politicheskaya elita $v$ Tatarstane: vyzovy vremeni $i$ trudnosti adaptatsii, "Polis", no. 6, pp. 67-79, http://www.politnauka.org/library/elit/farukshin.php. (access: 21.08.2020).

Gessen M.

2017 The Future Is History: How Totalitarianism Reclaimed Russia, New York.

Goonewardena K., Kipfer S.

2007 Colonization and the New Imperialism: On the Meaning of Urbicide Today, "Theory \& Event", vol. 10 (2), pp. 1-39.

Grafeyev Ye., Valeyev R.

2015 Okhrana kul'turnogo naslediya v Kazani s serediny 90-kh do 2010 g. in: R. Yusupov, R. Valeyev (eds.), Istoriko-kul'turnoye naslediye kak potentsial razvitiya turist.skorekreatsionnoy sfery. Materialy Mezhdunarodnoy nauchno-prakticheskoy konferentsii k Mezhdunarodnomu Dnyu pamyatnikov $i$ istoricheskikh mest, Kazan, pp. 54-60.

Graney K.

2007 Making Russia Multicultural. Kazan at its Millennium and Beyond, „Problems of Post-Communism", vol. 54 (6), pp.17-27.

Grodach C.

2002 Reconstituiting identity and history in post-war Mostar, Bosnia-Herzegovina, "City", vol. 6 (1), pp. 61-82.

Gullette D.

2010 The Genealogical Construction of the Kyrgyz Republic. Kinship, State and Tribalism, Cambridge.

Harvey D.

2012 Rebel Cities: From the Right to the City to the Urban Revolution, New York.

Huffschmid A., Wildner K.

2009 Räume sprechen, Diskurse verorten. Überlegung-en zu einer transdisziplinären Ethnographie, "Forum Qualitative Sozialforschung", vol. 10 (3), pp. 1-25.

Hughes C.F.

2007 The Influence of Ethnicity and Nationalism on Soviet and Post-Soviet Urbanization in Tallinn, Estonia and Kazan, Russia, "Geography Honors Projects", paper 12, https:// digitalcommons.macalester.edu/cgi/viewcontent.cgi? article=1011\&context=geograp hy_honors (access: 12.11.2020).

Jałowiecki B.

1988 Społeczne wytwarzanie przestrzeni, Warszawa.

Jasiewicz Z.

1987 Tradycja in: Z. Staszczak (ed.), Słownik etnologiczny. Terminy ogólne, WarszawaPoznań, pp. 353-358. 
Juskowiak P.

2015 Wywłaszczajaca urbanizacja. Miejski marksizm wobec problemu akumulacji pierwotnej, "Praktyka Teoretyczna”, vol. 2 (16), pp. 78-113.

Kinossian N.

2012 Post-socialist Transition and Remaking the City: Political Construction of Heritage in Tatarstan, "Europe-Asia Studies", vol. 64 (5), pp. 879-901.

Kusiak J.

2019 Legal Technologies of Primitive Accumulation: Judicial Robbery and Dispossessionby-Restitution in Warsaw, "International Journal of Urban and Regional Research", vol. 43 (4), pp. 649-665.

Lefebvre $\mathrm{H}$.

2003 The Urban Revolution, Minneapolis-London.

Makarychev A., Yatsyk A.

2015 Brands, Cities and (Post-)politics: A Comparative Analysis of Urban Strategies for the Universiade 2013 and the World Football Cup 2018 in Russia, "European Urban and Regional Studies", vol. 22 (2), pp. 143-160. Available at: https://doi. org/10.1177/0969776414548523 (access: 27.02.2019).

McCann L.

2005 Economic Development in Tatarstan. Global markets and a Russian region, Oxford.

Ovčinnikov A.

2017 "Vozrozhdeniye" Bolgara i Sviyazhska - noveyshiy opyt konstruirovaniya istoricheskoy pamyati, "Istoricheskiy format", no. 1-2, pp. 249-281.

Polyakova M.

2005 Okhrana kul'turnogo naslediya Rossii: ucheb. posobiye dlya vuzov, Moskva.

Ribarević-Nikolić I., Jurić Z. (eds.)

1992 Mostar '92: Urbicid, Mostar: HVO Opcine Mostar, Drustvo Arhitekata Mostar. Catalog of an exhibition of photo graphs documenting the destruction of Mostar's historic buildings and cultural institutions by Serbian shelling in 1992; incl. English text and captions.

Sassen S.

2014 Expulsions: Brutality and Complexity in the Global Economy, Cambridge, MAOxford.

Streule M.

2018 Ethnografie urbaner Territorien. Metropolitane Urbanisierungsprozesse von Mexiko-Stadt, Münster.

Szmyt Z.

2017 The Tight to the City: Indigenous Placemaking in Ulan-Ude, "Mongolica. An International Journal of Mongol Studies", vol. 51, pp. 200-212.

Torobekova V.

2013 "Clan Politics" or "Patron-Client" Relations in Post-Soviet Central Asia: In Postcolonial Discourse, https://src-h.slav.hokudai.ac.jp/jcrees/2013Osaka/53Torobekova.pdf (accessed: 25.03.2020).

Trubina E.

2011 Gorod v teorii: opyty osmysleniya prostranstva, Moskva.

2015 Mega-events in the Context of Capitalist Modernity: The case of 2014 Sochi Winter Olympics, "Eurasian Geography and Economics", vol. 55 (6), pp. 1-18. 
Tsybul'skiy I., Shaydullina N.

2016 Mintimer Shaimiev, Moskva.

Turowska A.

2019 Social Production of Space in Kazan: Between Urban Entrepreneurialism and Bottom-up Activism in: N. Camprag, A. Suri (eds.), Three Decades of Post-Socialist Transition, Darmstadt, pp. 364-373.

Valeyev A.R.

2010 Realizatsiya programmy likvidatsii vetkhogo zhil'ya $v$ respublike Tatarstan $v 1995-$ 2004 godakh, "Vestnik TGGPU”, no. 4 (22).

Veselova E.

2015 Chto delayet Tatarstan uspeshnym regionom, "Eko", no. 1 (487), pp. 5-25.

Weber M.

2002 Gospodarka i społeczeństwo. Zarys socjologii rozumiejącej, Warszawa.

Yasaveyev I.

2013 "Sdvinut' glybu": opyt publichnoй sotsiologii v ramkakh universitet.skogo kursa in: Ye. Yarskaya-Smirnova, P. Romanov (eds.), Publichnaya sfera: teoriya, metodologiya, keřs stadi: kollektiv. monogr, Biblioteka "Zhurnala issledovaniǔ sotsial'noĭ politiki", Moskva, pp. 105-122.

Załęski P.

2011 Kultura polityczna więzi w Azji Centralnej (przypadek Kirgistanu na tle państw regionu), Warszawa.

Zharzhevskiy L.

2019 O kazan'skoy starine i ne tol'ko: sbornik sat'yey, Kazan.Zhelnina A.

Zhelnina A.,

2019 The Apathy Syndrome: How We Are Trained Not to Care about Politics, "Social Problems", no. 67 (2), pp. 358-378.

Zhelnina A., Tykanova E.

2019 Formal'nyye i neformal'nyye grazhdanskiye infrastruktury: sovremennyye issledovaniya gorodskogo lokal'nogo aktivizma $v$ Rossii, "Zhurnal sotsiologii i sotsialnoy antropologii", no. 22 (1), pp. 162-192.

Minnikhanov raskritikoval glavnogo arkhitektora Kazani za vysotnyye zdaniya $v$ tsentre stolitsy, https://www.youtube.com/watch? $\mathrm{v}=\mathrm{cWm3mDjTUtM} \mathrm{(access:} \mathrm{15.07.2020).}$

"On znayet zhizn": 17 mgnoveniy vesny Rustama Minnikhanova;

24.02.2017, https://www.business-gazeta.ru/article/338446 (access: 10.10.2020).

Resheniye KSND

ot 30.10.1996 N 1-5 "O programme likvidatsii vetkhogo zhilogo fonda i rekonstruktsii kvartalov vetkhogo zhil'ya v Kazani” // Respublika Tatarstan.) // Respublika Tatarstan. (Решение КСНД от 30.10.1996 N 1-5 “О программе ликвидаиии ветхого жилого фонда и реконструкиии кварталов ветхого жилья в Казани” // Республика Татарстан), http://tatarstan.news- city.info/ docs2/sistemaf/dok_pedhfi/index.htm (access: 1.10.2020).

https://yeltsin.ru/news/boris-elcin-berite-stolko-suverineteta-skolko-smozhete-proglotit/ (access: 1.10.2020).

$V$ tsentre Kazani ne budut stroit' mnogoetazhnoye zhil'ye https://www.tatre.ru/articles_id19090 (access: 29.10.2020). 